\title{
Figurações da personagem detetivesca
}

\author{
Figurations of the detective character
}

Marta Maria Rodriguez Nebias

Universidade do Estado do Rio de Janeiro - Rio de Janeiro - Brasil

\author{
$\diamond$
}

\begin{abstract}
Resumo: Este artigo pretende traçar um panorama histórico da ficção policial, desde as suas primeiras manifestações, no século XIX, até as manifestações contemporâneas, buscando comprovar que a configuração da personagem detetivesca está sempre em consonância com o contexto social no qual se insere. Em um primeiro momento, analisaremos o detetive do chamado romance de enigma, surgido no século XIX, cujos maiores representantes são Dupin e Sherlock Holmes. Posteriormente, analisaremos o novo tipo de narrativa policial que surgiu no início do século XX, que pode ser considerada um desdobramento do policial de enigma: o romance negro (roman-noir), representado pelas personagens Philip Marlowe e Sam Spade. Por fim, teceremos considerações sobre o detetive contemporâneo, enfocando a personagem Mandrake, de Rubem Fonseca.
\end{abstract}

Palavras-chave: Fiç̧ão policial; Detetive; Personagem.

\begin{abstract}
This article intends to trace a historical panorama of detective fiction, from its first manifestations in the nineteenth century to the contemporary manifestations, seeking to prove that the configuration of the detective character is always in harmony with the social context in which it is inserted. At first, we will analyze the detective of the so-called "puzzle novel", which emerged in the nineteenth century, whose greatest representatives are Dupin and Sherlock Holmes. Later, we will analyze the new type of detective novel' narrative that emerged in the early twentieth century, which may be considered as an outgrowth of the "puzzle novel": the roman-noir, represented by the characters Philip Marlowe and Sam Spade. Finally, we will make considerations about the contemporary detective, focusing on the character Mandrake, by Rubem Fonseca.
\end{abstract}

Keywords: Detective fiction; Detective; Character

\section{Introdução}

Antonio Candido, ao definir a personagem como "um ser fictício", chama atenção para o fato de tal expressão soar como um paradoxo:

(...) como pode uma ficção ser? Como pode existir o que não existe? No entanto, a criação literária repousa sobre este paradoxo, e o problema da verossimilhança no romance depende desta possibilidade de um ser fictício, isto é, algo que, sendo criação da fantasia, comunica a impressão da mais lídima verdade existencial. Podemos dizer, portanto, que o romance se baseia, antes de mais nada, num certo tipo de relação entre o ser vivo e o ser fictício, manifestada através da personagem, que é a concretização deste (2009, p. 55).

Assim, paradoxalmente, a personagem, apesar de ser uma criação da fantasia, um "ser de papel”, deve ter uma relação de verossimilhança com a realidade, pois como ressaltam Oswald Ducrot e Tzvetan Todorov, "personagens representam pessoas, segundo modalidades próprias da ficção" (apud BRAIT, 1985, p. 11).

Algumas personagens se fixam no imaginário coletivo de tal forma que chegam a ser confundidas com um ser vivo, real. Um exemplo é Sherlock Holmes, uma das personagens mais marcantes da história da literatura. Paulo de Medeiros e Albuquerque (1979, p.48/49) revela um fato curioso sobre o detetive criado por Conan Doyle: durante anos, foram endereçadas cartas ao número $221 \mathrm{~B}$ de Baker Street, seu endereço "fictício", e tais cartas continham tanto elogios à sua performance, quanto ofertas de trabalho. Ou seja, o fascínio provocado pelo mito Sherlock Holmes é tanto que chega a subverter a ideia da personagem como um ser de papel. 
Esse fascínio foi fundamental para o florescimento do gênero policial. No que tange ao gênero em questão, percebemos que a personagem detetivesca ocupa uma posição crucial na trama, e sua configuração acompanha o momento histórico em que surge. Dessa forma, vemos em Sherlock, com sua racionalidade e cientificismo, um fruto, ainda que tardio, do Iluminismo.

Do mesmo modo, identificamos em Sam Spade e Philip Marlowe, detetives criados por Dashiell Hammett e Raymond Chandler, um reflexo da sociedade da época em que surgiram, os Estados Unidos dos anos 1920, vitimados pelo caos instaurado com a quebra da bolsa de Nova Iorque e com o consequente aumento da corrupção e da violência. Em um contexto tão conturbado, não faria sentido a configuração de um detetive como Sherlock, metódico e cerebral, mas a de um detetive mais humanizado, que em vez de utilizar métodos científicos para solucionar o mistério, utiliza a intuição e a força.

Já na ficção brasileira atual, assistimos ao surgimento de um detetive que dialoga com os modelos anteriores, principalmente com os da escola americana, mas que está imerso em um ceticismo proveniente de uma sociedade que perdeu a inocência e não acredita mais em verdades absolutas.

O presente estudo, portanto, pretende delinear a trajetória da narrativa policial, desde aquela que é considerada a sua primeira manifestação até suas manifestações contemporâneas, buscando comprovar que a personagem detetivesca se configura em conjugação com os períodos literários e sociais nos quais se insere, como observa Paulo de Medeiros e Albuquerque:

A figura do detetive no romance policial vem sofrendo uma série de transformações através dos tempos. E o estudo dessas várias figuras mostra-nos a evolução do romance de mistério. Que fabulosa diferença entre o Dupin, de Edgar Allan Poe, ou o Sherlock Holmes, de Conan Doyle de ontem, dos Chester Drum, Shell Scott e outros dos dias de hoje! Frutos das épocas em que foram criados, os primeiros refletem em suas atitudes e seus métodos o fim do século passado, enquanto os últimos o que há de pior na agitada, nervosa e tumultuada vida de nossos dias (1979, p. 37).

\section{O detetive máquina}

Segundo Róman Gubern, parece indiscutível "o fato de que o romance policial nasce precisamente no período da revolução industrial e da luta de classes, ao correr do século XIX” (apud Matraga, p. 44).

$\mathrm{O}$ nascimento do romance policial condicionou-se a uma série de circunstâncias. A primeira delas foi o surgimento da cidade industrial, pois conforme observa Francis Lacassin em Mythologie du roman policier", "a cidade é, ao mesmo tempo, para o detetive sua cúmplice, sua adversária e sua companheira. Ela é o símbolo do fantástico acaçapado sob a máscara do cotidiano..." (apud Bouileau-Narcejac, 1991, p. 14).

O deslocamento de milhares de pessoas do campo para a cidade ocasionado pela Revolução Industrial propiciou o rápido crescimento dos centros urbanos. Em meio a essa massa urbana, em que todos são anônimos, viabiliza-se a figura do criminoso, que se beneficia desse anonimato para se esconder, como sintetiza Walter Benjamin: "O conteúdo social primitivo do romance policial é a supressão dos vestígios do indivíduo na multidão da cidade grande" $(1989$, p. 41).

Com o desenvolvimento da cidade, e em virtude da necessidade de controle sobre as massas, desenvolve-se também a polícia. Antes do século XVIII, a punição era baseada na confissão, em honra do soberano. Nos séculos XVIII e XIX, entretanto, surge um aparelho social baseado na lógica da investigação. Segundo Foucault, "o direito de punir deslocou-se da vingança do soberano à defesa da sociedade (1987, p. 76). O objetivo agora passa a ser evitar o crime através da punição prévia e da polícia ostensiva. Desse modo, surge a figura do investigador, como uma espécie de herói moderno, defensor da sociedade. De acordo com Sergei Mijailovich Eisenstein:

No início do século XIX, que coincide com o desenvolvimento da burguesia, quem se destaca como protagonista é o aventureiro, o criminoso - o Conde de Montecristo, Rocambole. Esses heróis são ligados ao protesto romântico e portanto são magnânimos. A partir da segunda metade do século XIX, quem se converte em protagonista é o investigador, o tutor de patrimônio, o que "pesca" os canalhas que ousam atentar contra a propriedade (apud Matraga, p. 49).

A terceira circunstância que contribuiu com o surgimento do gênero policial foi o desenvolvimento dos jornais. A grande imprensa criou o "fato do dia", que podia ser um relato banal sobre algum incêndio ou acidente, ou sobre um crime misterioso. Esse gênero de relato, como apontam Boileau e Narcejac, "provoca um prazer intenso: encanto do mistério, emoção produzida pelo espetáculo da infelicidade, desejo de justiça, etc.” (1991, p. 15). Criam-se as prerrogativas para o surgimento do folhetim, a chamada "literatura industrial", nas palavras de Sainte-Beuve (apud MEYER, 1996, p. 55), fundamental para a propagação das narrativas de crime e mistério. Em "Os crimes da Rua Morgue", de Poe, primeira narrativa considerada policial, o detetive decifra o enigma através da leitura de recortes de jornais.

No século XIX também se destaca o desenvolvimento da ciência, reflexo do Iluminismo, com a prevalência do positivismo como escola filosófica. Segundo Gustavo 
Bernardo Krause, acreditava-se que a certeza sobre a realidade, propiciada pela ciência, encontrava-se muito próxima. Por isso, "a ficção desse período se esmerava em emular os procedimentos científicos na sua prática discursiva" (2004, p. 24).

Naquela época em que o conhecimento científico é considerado a única forma de conhecimento verdadeiro, e em que o criminoso é visto como um inimigo social, surge uma espécie de literatura que sintetiza todo esse espírito: a policial. Em abril de 1841, portanto, é publicado nas páginas da Graham's Magazine, o conto de Edgar Allan Poe que seria considerado pelos estudiosos a primeira narrativa policial, inaugurando assim a escola de enigma.

O presente trabalho, como já mencionamos, propõe analisar a "evolução" da personagem detetivesca ao longo dos tempos, e comprovar sua consonância com o momento histórico em que surge. Podemos então considerar que Chevalier C. Auguste Dupin atende perfeitamente a nossa pretensão, sendo "o primeiro investigador fictício a confiar primordialmente na dedução a partir de fatos observáveis" (JAMES, 2009, p. 34/35). Em outras palavras, Dupin foi a primeira personagem a colocar em prática as teorias positivistas que estavam em voga na época.

A primeira narrativa policial já apresenta no primeiro parágrafo uma tese que será o cerne da recém fundada escola de enigma:

As faculdades do espírito definidas pelo termo analíticas são, em si, pouco suscetíveis de análise. Apreciamo-las apenas pelos seus resultados. O que dela sabemos, entre outras coisas, é que são para quem as possui em grau extraordinário fonte de prazeres dos mais vivos. Assim como o homem forte se rejubila com a aptidão física e se compraz nos exercícios que compelem os músculos à ação, assim também o analista se orgulha da atividade espiritual cuja função é desemaranhar. Encontra prazer até nas mais triviais ocasiões que lhe desafiam o talento. Gosta de enigmas, de rébus, de hieróglifos, e revela em cada uma das soluções um poder de perspicácia que, na opinião vulgar, assume caráter sobrenatural. Os resultados, habilmente deduzidos pela própria alma e essência do seu método, possuem, na realidade, todo o aspecto de uma intuição (POE, 1961, p. 01).

O narrador nos expõe o método analítico de Dupin, que irá influenciar os detetives posteriores, "cuja função é desemaranhar". Como vimos, a narrativa de Poe está inserida em um contexto que induz a essa ênfase no raciocínio e na lógica, colocando a investigação científica em primeiro plano. Dupin é representante do bem e da ordem, e estes só prevalecem quando a verdade é atingida, como apregoa o detetive: "O meu objetivo final é a verdade" (POE, 1961, p. 26).
Detetive, do latim detectare, é aquele que detecta, que descobre, que desmascara. Em outras palavras, é aquele que encontra a verdade. Nesse sentido, "Dupin é a personificação do espírito cientificista da época" (CARNEIRO, 2005, p. 19), uma época em que a verdade una, absoluta, é alcançada através do raciocínio lógico.

É importante nos atermos ao narrador, que ocupa uma posição estratégica nos romances de enigma. $\mathrm{O}$ narrador de Os Crimes da Rua Morgue e dos outros contos cujo protagonista é Dupin, $O$ Mistério de Maria Roget e $A$ Carta Roubada, é um grande admirador do detetive, conforme se observa no trecho abaixo, em que ele narra como ambos se conheceram:

O nosso primeiro conhecimento realizou-se numa escura sala de leitura da rua Montmartre, pelo acaso de estarmos ambos à procura do mesmo livro, bastante notável e raro; a coincidência nos aproximou. Víamo-nos cada vez mais. Interessou-me profundamente a sua história de família que me contou minuciosamente com a candura e o abandono a que se entrega todo francês, quando fala apenas do próprio eu. Assombrou-me também a prodigiosa extensão de suas leituras e, sobretudo senti a alma absorta pelo estranho calor e frescor vital de sua imaginação. Procurando em Paris alguns objetos que constituíam o meu único estudo, percebi que a companhia de semelhante homem seria para mim tesouro inestimável, e a partir de então dediquei-me francamente a ele. (...) Vivíamos apenas dentro de nós (POE, 1961, p. 05).

Além de demonstrar grande admiração por Dupin, o narrador mostra também uma grande identificação e até uma simbiose: "vivíamos apenas dentro de nós". Não há nada na narrativa que indique seu nome ou aparência física, sua preocupação é descrever e realçar as qualidades do detetive, que se contrapõem às suas.

A função dessa personagem, de capacidades medianas, é conservar o mistério e intensificar a admiração pelo detetive, exaltando sua superioridade intelectual. Através da figura do narrador-personagem, constrói-se uma ambiguidade no texto, gerada pelo contraste entre os dois personagens que, apesar de opostos, também são complementares.

Se no século XIX o mundo é visto como uma máquina, o mesmo podemos dizer do detetive engendrado por Poe, uma "máquina de pensar". Flávio Carneiro assinala que "Dupin é a personificação do espírito cientificista da época, do amor à observação minuciosa e racional dos fatos, da atração irresistível pela descoberta, é o homem que detecta" (2005, p. 19/20).

Edgar Allan Poe, através de Dupin, criou o protótipo do detetive, abrindo o caminho para os seus posteriores desdobramentos, dentre os quais se destaca aquele que 
surgiria quarenta e seis anos depois e que se tornaria um paradigma: Sherlock Holmes. Segundo P. D. James,

Poe não descreveu a si mesmo como um escritor de histórias de detetive, mas tanto ele como seu herói, C. Auguste Dupin, tiveram sua devida importância na história do gênero, embora Dupin não possa desafiar a predominância de Sherlock Holmes e tenha pouco em comum com este, a não ser sua capacidade de dedução. Sherlock Holmes permanece único (2012, p.35-36).

De fato, Sherlock Holmes foi uma das personagens mais bem-sucedidas na história da literatura e criou tamanha empatia com seus leitores que o seu autor, Conan Doyle, teve que ressuscitá-lo para acalmar o ânimo dos fãs, inconformados com a morte da personagem.

Já em sua primeira aparição, a novela Um estudo em vermelho, publicada em 1887, Holmes é comparado por Watson àquele que é considerado o "primeiro detetive digno desse nome" (ALBUQUERQUE, 1979, p. 37): "Você me faz lembrar o Dupin de Edgar Allan Poe. Eu não tinha a menor ideia de que tais pessoas existissem fora das histórias". Entretanto, tal comparação parece não agradar ao detetive, que retruca: "sem dúvida, você acha que está me elogiando, comparando-me a Dupin (...) Pois, na minha opinião, Dupin era um sujeito bem inferior (...) Tinha certo gênio analítico, sem dúvida; mas não era de jeito nenhum o fenômeno que Poe parecia imaginar" (DOYLE,2014, p. 26). Ao inferiorizar Dupin em relação a si mesmo, Holmes declara sua tão característica essência narcisista.

O narrador das aventuras de Sherlock, seguindo a linha iniciada por Poe, é um amigo do detetive. Beth Brait lembra que "qualquer tentativa de sintetizar as maneiras possíveis de caracterização de personagens esbarra necessariamente na questão do narrador, esta instância narrativa que vai conduzindo o leitor por um mundo que parece estar se criando à sua frente" $(1985$, p. 52). O narrador é quem permite a visualização, a materialização da personagem, que é construída através de vários recursos diferentes. No caso de Sherlock e Watson, a personagem principal é apresentada ao leitor através de um narrador- testemunha:

O discurso de Watson, narrador e personagem auxiliar de Sherlock, vai construindo, pela referência aos hábitos, pela seleção de traços e atributos, pela narração de ações e pela instauração de diálogos, o perfil de uma personagem, que ganha o primeiro plano e deixa à atividade do narrador a função de testemunha exclusiva, capaz de presentificar, pela ilusão do registro, a sua materialidade. Privando da intimidade desse "herói", ao nível do discurso e da intriga, a personagem-narrador funciona como a lente privilegiada através da qual o leitor recebe e visualiza as personagens (BRAIT, 1985, p. 64)
O mesmo pode ser dito do narrador de "Os crimes da Rua Morgue". Entretanto, o narrador de Poe não exterioriza suas características pessoais, o que não se aplica às narrativas de Conan Doyle. Watson explicita suas próprias características que, contudo, não são muito favoráveis, pois o que sobressai é a sua inferioridade intelectual em relação ao protagonista, inferioridade que este faz questão de acentuar: "Com todos esses dados você já deveria ser capaz de alguma inferência" (p. 176).

Watson seleciona as aventuras de Sherlock Holmes que devem ser narradas, o que lhe transmite certa autonomia em relação ao detetive. Além de escolher o que será narrado, opta por sua forma de narração, que nem sempre se harmoniza com o que Holmes crê que deveria ser a narrativa de seus feitos. Ao comentar com o detetive que relatou sua primeira aventura juntos "numa pequena brochura com o título um tanto fantástico de Um estudo em vermelho", Holmes declara:

\begin{abstract}
- Dei uma olhada nela. (...) Honestamente, não posso congratulá-lo. A detecção é, ou deveria ser, uma ciência exata, e deveria ser tratada da mesma maneira fria e sem envolvimento emocional. Você tentou pintá-la com romantismo, o que dá o mesmo efeito de elaborar uma história de amor ou de fuga com o auxílio do quinto postulado de Euclides (2014, p. 127).
\end{abstract}

No trecho acima, ressalta-se a frieza de Sherlock, que se baseia na tese de que "as qualidades emocionais são antagonistas do raciocínio claro" (2014, p. 127), reafirmando o espírito racionalista da época.

A relação simbiótica entre as personagens Watson e Sherlock só encontra similitude na história da literatura, talvez, com a de Dom Quixote e Sancho Pança, o que já chegou a ser objeto de reflexão de Jorge Luís Borges. A noção do detetive e seu assistente como faces complementares é tão exacerbada que não se consegue dissociar a imagem de Sherlock à de Watson. De um lado, temos toda a genialidade de Sherlock, de outro, a mediocridade de Watson, características opostas, mas, ao mesmo tempo, complementares, pois a obstrução mental de Watson ressalta a intelectualidade de Holmes, como menciona o próprio Conan Doyle:

Ele [Holmes] não poderia contar suas próprias aventuras. Era-lhe necessário, portanto, um camarada banal, comum, que o valorizasse por contraste; um nome terno e discreto para essa personagem sem brilho: Watson, serviria (apud ALBUQUERQUE, 1979, p. 90).

Como nosso objetivo primordial é a análise da personagem, cabe fazermos uma breve interrupção para tratarmos do estudo de E. M. Forster sobre o tema. Seu livro Aspectos do romance foi publicado em um momento 
de oposição aos métodos da história literária positivista. A personagem deixa de ser apreendida por referência a elementos exteriores, passando a ser vista em sua relação com as demais partes da obra. Em outras palavras, a narrativa passa a ser encarada como um sistema.

Forster separa as personagens, de acordo com sua complexidade, em flat (plana) e round (redonda). As primeiras são confeccionadas a partir de uma única ideia e podem ser divididas em "tipo" e "caricatura". Classificam-se como "tipos" as personagens que geralmente estão relacionadas a um papel social, ou seja, que são construídas ao redor de generalizações baseadas em características comuns aos elementos de um grupo. Quando a característica é levada ao extremo, a personagem passa a ser uma "caricatura".

Já as personagens que se classificam como "redondas" são seres fictícios complexos, que apresentam várias qualidades. Tomemos como exemplo Sherlock Holmes e sua descrição feita por Watson em Um estudo em vermelho:

A energia de Holmes, quando mergulhava no trabalho, era insuperável. Mas, depois, sobrevinha-lhe uma reação e ele passava os dias estirado sobre o sofá da sala, sem articular uma palavra e sem mover um músculo da manhã à noite. Nesses períodos, percebia uma expressão tão vaga e onírica em seus olhos, que teria suspeitado do uso de algum narcótico, se a sobriedade e a correção de sua vida não me impedissem de pensar tal coisa.

À medida que as semanas passavam, meu interesse por ele e a curiosidade pelos objetivos de sua vida cresciam cada vez mais. Ele próprio, com sua aparência, chamava a atenção do observador mais casual.

Media em torno de um e oitenta de altura, mas era tão magro que dava impressão de ser ainda mais alto. Seu olhar era aguçado e penetrante, a não ser naqueles períodos de torpor a que já me referi. $\mathrm{O}$ nariz, fino e adunco como o de um falcão, dava ao semblante um ar de vivacidade e decisão. Também o queixo, quadrado e proeminente, caracterizava-o como homem de determinação. Suas mãos estavam sempre manchadas com tinta e produtos químicos, mas seu toque era muito delicado, conforme pude observar inúmeras vezes, enquanto ele manipulava seus frágeis instrumentos de alquimista (2004, p. 19).

Watson, intrigado com a tão complexa personalidade do detetive, chega a listar seus conhecimentos:

Sherlock Holmes - seus limites

1. Conhecimento de literatura: nulo.

2. Conhecimento de filosofia: nulo.

3. Conhecimento de astronomia: nulo.

4. Conhecimento de política: fraco.
5. Conhecimento de botânica: variável. Entende de beladona, ópio e venenos em geral. Não sabe nada sobre plantas úteis.

6. Conhecimento de geologia: prático, mas limitado. Distingue, à primeira

vista, diferentes tipos de solos. Depois de suas caminhadas, mostra-me manchas em suas calças e diz, a partir da cor e da consistência, de que parte de Londres são.

7. Conhecimento de química: profundo.

8. Conhecimento de anatomia: acurado, mas assistemático.

9. Conhecimento de publicações sensacionalistas: imenso. Parece conhecer cada detalhe de todos os horrores perpetrados neste século.

10. Toca violino bem.

11. Perito em esgrima e boxe. Um espadachim.

12. Bom conhecimento prático das leis inglesas (2004, p. 21-22).

Percebemos na descrição de Watson características físicas, psicológicas, sociais e ideológicas, o que faz de Holmes uma personagem complexa, encaixando-se no que Forster denomina "personagem redonda".

Voltemos, pois, à análise da personagem detetivesca e sua relação com a sociedade do século XIX. Como observa Ricardo Piglia, no romance de enigma "valorizase, antes de mais nada, a onipotência do pensamento e a lógica imbatível dos personagens encarregados de proteger a vida burguesa" (1994, p.78). É importante destacarmos que na sociedade em questão as fronteiras entre ordem e desordem, lei e crime, bem e mal, herói e vilão, são muito bem definidas. O detetive é o herói que vai resgatar a ordem através de métodos científicos pautados na observação e dedução.

Sherlock chega a lamentar que "hoje em dia não há mais crimes nem criminosos" (2004, p. 27). E completa:

De que adianta cérebro em nossa profissão? Sei que tenho inteligência suficiente para ser um nome famoso. Não há e jamais houve alguém com a profundidade de conhecimentos e o talento natural para a investigação de crimes que tenho. E para quê? Não há crimes para desvendar. No máximo, alguma vilania mal executada e causada por motivos tão transparentes, que até um oficial da Scotland Yard consegue resolver (2004, p. 27).

Se na sociedade inglesa do século XIX o crime era exceção, o mesmo não se pode dizer da sociedade que serviu de berço para o chamado roman noir, como veremos a seguir.

\section{O detetive "durão"}

No século XX, com a emergência de novas configurações sociais, políticas e culturais, o pensamento 
positivista passa a ser questionado. Surge, entre as décadas de 20 e 30, um desdobramento daquele tipo de narrativa que exalta o raciocínio e a lógica como meios de alcançar a verdade: o romance negro (roman-noir).

Segundo Ernest Mandel, com o surgimento do romance negro, ocorre a "primeira grande revolução no romance policial" (1988, p.63), cujas figuras predominantes foram Dashiell Hammet, com seu detetive Samuel Spade, e Raymond Chandler, com o detetive Philip Marlowe. Tanto os pesquisadores quanto Raymond Chandler concordam que coube a Hammett a invenção do roman-noir, que veio à tona com a revista Black Mask, fundada em 1920 .

A narrativa noir espelha a sociedade americana da época, que se encontrava sob o contexto de grande confusão política que se seguiu à Primeira Guerra Mundial, o chamado "período de desilusão". De acordo com Mandel, "com a Lei Seca nos Estados Unidos, o crime atingiu sua maioridade, se expandindo das margens da sociedade burguesa até o âmago de todas as atividades" (1988, p. 59). E mais, com a chegada da Depressão, ocorre a "expansão quantitativa do crime" e sua "transformação qualitativa, com o consequente domínio do crime organizado" (1988, p. 59).

Este contexto torna inverossímil aquela narrativa de espaço fechado em que o detetive infalível desvenda o caso através do raciocínio lógico, sem a necessidade de ir ao local do crime. O detetive da narrativa noir não trabalha por diletantismo, é um detetive profissional, assalariado, que precisa ir às ruas para perseguir os suspeitos.

Ernest Mandel observa que "a evolução do romance policial reflete a própria história do crime" (1988, p.59). Ainda segundo o estudioso, "a maioridade do crime organizado colocou um ponto final no romance policial ambientado na sala de visitas. É impossível se imaginar Hercule Poirot (...) lutando contra a Máfia" (1988, p. 62).

No romance de enigma, o assassino era uma espécie de "detetive do avesso", uma "réplica do detetive" (BOILEAU e NARCEJAC, 1991, p. 57), pois a própria noção de o detetive ser mais esperto que o criminoso implica a existência de um criminoso de grande inteligência, porém, inferior à do detetive. No romance negro, invertem-se os papéis. O detetive passa a ser uma "réplica do assassino", uma espécie de "criminoso do avesso" (BOILEAU e NARCEJAC, 1991, p.57). O enigma cede lugar à violência.

A figura do assistente narrador desaparece no romance negro. Os fatos costumam ser narrados pelo próprio detetive, que conhece apenas aquilo de que participa diretamente. Ciente de sua limitação, ele narra suas aventuras e fracassos, já que não é mais aquele ser infalível capaz de solucionar qualquer mistério através do raciocínio lógico. Apesar de ser mais comum esse tipo de narrativa, podemos encontrar também um narrador impessoal, onisciente em relação apenas à ação, por não possuir acesso aos sentimentos dos personagens.

O roman-noir imita a realidade que o circunscreve, ou seja, imita o clima de desilusão que pairava na sociedade americana da época. Flávio Carneiro observa que o detetive protagonista das narrativas de Hammett, Sam Spade, "é o espelho da crise americana do final dos anos 20, em que o sonho se transformara em pesadelo e um detetive como Dupin pareceria completamente despropositado" (2005, p. 20). De fato, como mencionado por Ernest Mandel, seria difícil conceber detetives cerebrais como Dupin ou Sherlock lutando contra a Máfia.

Cabe destacar que, apesar da tendência de pensar o gênero policial como retrato da realidade, o seu estatuto não é o da realidade pura. O principal é o jogo do raciocínio, no caso do romance de enigma, e o da intuição, no caso do roman noir. A evolução do pensamento para a ação, segundo Ernest Mandel, é a chave para a transformação interna do gênero. Os detetives clássicos não agem, pensam, enquanto os detetives "durões" do romance negro não pensam, agem seguindo a sua intuição.

Os detetives do romance negro, apesar de cínicos e, aparentemente, insensíveis, mascaram um certo romantismo. Conservam a utopia de serem capazes de combater o crime organizado e a corrupção, "à dom Quixote", o que, segundo Mandel, revela "uma certa dose de fantasia adolescente no seu conteúdo e nenhuma relação com a realidade social das décadas de 20 e 30 " (1988, p. 64).

O romance negro, reiteremos, é um desdobramento do romance de enigma em que o detetive passa a ser um desdobramento do criminoso, gerando um certo relativismo no que concerne à polarização maniqueísta do gênero policial. Entretanto, apesar de sua falibilidade e da sua identificação com o criminoso - fala como ele, veste-se como ele, é brutal como ele -, o detetive ainda é o herói que se contrapõe ao vilão. É esse detetive, mais humanizado, que servirá de modelo para as manifestações brasileiras.

\section{O detetive contemporâneo}

Paulo de Medeiros e Albuquerque, em $O$ mundo emocionante do romance policial, afirma que o precursor do gênero no Brasil foi seu avô, Medeiros e Albuquerque. Muitos estudiosos concordam com esta asserção e apontam que a primeira narrativa policial brasileira foi $O$ mistério, folhetim escrito por Afrânio Peixoto, Viriato Correia, Coelho Netto e Medeiros e Albuquerque.

A ficção policial propriamente dita surgiria no Brasil, portanto, em 1920, ou seja, quase um século depois da 
narrativa de Edgar Allan Poe, também sob a forma de folhetim. Entretanto, cabe frisar que no século XIX já existiam algumas manifestações, ainda que embrionárias, do gênero, e alguns estudiosos consideram que a glória de precursor da narrativa policial no Brasil se deve a Aluízio Azevedo, com a publicação de Mattos, Malta, Matta?

Essa discussão acerca do verdadeiro precursor da narrativa policial brasileira é, para este estudo, irrelevante. O importante é reconhecer que a sociedade brasileira está mais próxima dos conflitos sociais vivenciados pelos Estados Unidos no final da década de 1920, do que do cientificismo vivido pela Inglaterra no século XIX. Como observa Vera Lúcia Follain de Figueiredo:

As obras iniciais já apontam a dificuldade de lidarmos com a ideia de uma sociedade justa em que o crime surgia como exceção, marginalidade a ser combatida para que o equilíbrio se restabelecesse. (...) A importação do modelo europeu, comum em nossa cultura, quando se trata do romance policial clássico, suscitava impasses imediatos para o escritor, em virtude do tratamento dado ao tema, que envolve questões como o papel do parelho judicial, da polícia, a organização da sociedade e o próprio valor conferido à vida $(1988$, p. 21).

Assim, o modelo de detetive adotado por nós, segundo Flávio Carneiro, será Sam Spade que, ao contrário de Dupin, é "um detetive mais humanizado, menos máquina, um homem comum, que se envolve com prostitutas, que fuma e bebe muito, que age movido mais pela intuição do que por métodos científicos" (2005, p. 20).

Apesar de algumas esparsas manifestações entre os séculos XIX e meados do século XX, podemos considerar que a narrativa policial só vai vingar no Brasil a partir dos anos 80 , já que agora encontra solo fértil, em função da ausência de maiores motivações políticas, da generalizada descrença em projetos de transformação, permitindo que o olhar se volte para a decadência da sociedade e abrindo caminho para a atitude nostálgica e, ao mesmo tempo, negativa que caracteriza o detetive do roman-noir, mergulhado no cinismo, através do qual disfarça a persistência de ideais românticos, inadequados ao contexto (FIGUEIREDO,1988, p. 21).

Vera Lúcia Follain de Figueiredo, ao analisar a narrativa policial de Rubem Fonseca, fundamental para a revitalização do gênero policial, considera que o personagem fonsequiano refaz o percurso do pensamento para a ação, proposto por Ernest Mandel, "para chegar a um ponto ainda mais adiante: o uso da imaginação para criar versões plausíveis". E prossegue: "na indagação sobre a verdade, questiona-se não só a dedução lógica do romance de enigma, a eficácia da técnica analítica, mas também a experiência concreta da perseguição do suspeito, como caminho para atingir o sentido último dos fatos" (2003, p. 44). Assim, o detetive contemporâneo utiliza a imaginação para construir a sua verdade que, por sua vez, "não passa de uma construção discursiva, de uma versão plausível" (FIGUEIREDO, 1988, p. 23).

Percebemos então o surgimento de um detetive que está mais de acordo com nossas condições culturais, sem deixar de dialogar com as escolas anteriores. Trataremos a seguir de um dos maiores exemplos desse detetive reinventado: a personagem Mandrake.

Em A grande arte, de Rubem Fonseca, o detetive Mandrake não utiliza como meio de investigação a dedução lógica, como o detetive clássico, mas a intuição e, principalmente, a imaginação:

Os acontecimentos foram sabidos e compreendidos mediante minha observação pessoal, direta, ou então segundo o testemunho de alguns dos envolvidos. Às vezes interpretei episódios e comportamentos - não fosse eu um advogado acostumado, profissionalmente, ao exercício da hermenêutica (FONSECA, 1983, p. 08).

A busca da verdade através da dedução lógica e da ação é substituída pela imaginação, pois segundo Vera Lúcia Follain, "nem a observação direta, nem a dedução lógica são suficientes para a apreensão de toda complexidade do comportamento humano" (FIGUEIREDO, 1988, p.23), já que "o comportamento humano não é lógico e o crime é humano" (FONSECA, 1983, p. 27).

Mandrake, ao perceber a impossibilidade de chegar a uma verdade, constrói uma versão verossímil para os fatos através, principalmente, da leitura de textos alheios, como o diário de Lima Prado, usando, segundo o detetive, "suas próprias palavras, muitas vezes, retiradas diretamente dos Cadernos, procurando preservar os efeitos literários que ele buscava, afinal, Lima Prado se julgava um homem de letras" (FONSECA, 1983, p. 172). Rubem Fonseca se apropria da ideia do detetive como "leitor do mundo", aquele que lê pistas, decodifica sinais, e transforma Mandrake em um leitor de verdade, que "gostava de ficar lendo na cama, de manhã, antes de ir para o escritório" (FONSECA, 1983, p. 38).

Esse predomínio da imaginação, que encontramos em Mandrake, caracteriza o detetive contemporâneo, em oposição ao detetive clássico, que privilegia o raciocínio, o pensamento lógico, e o detetive noir, que privilegia $\mathrm{o}$ instinto e a ação como meios de atingir a verdade. $\mathrm{O}$ detetive contemporâneo tem consciência de que esta não passa de uma construção discursiva, na maioria das vezes, inatingível: "não existem verdades absolutas, mas obsoletas" (FONSECA, 1983, p. 287). 
Os principais traços do romance policial são mantidos por Rubem Fonseca, porém, sob uma forma de reescritura. Assim, vemos em Mandrake uma reescritura dos detetives anteriores, principalmente dos detetives do romance negro, pois está ligado ao mundo do crime - é um advogado criminal - e se envolve na perseguição dos suspeitos. Como o detetive noir, Mandrake é também um homem de ação, como se observa na declaração da personagem Lilibeth: "O dr. Medeiros disse que o senhor é um homem de ação, para eu não perder tempo com rodeios" (FONSECA, 1983, p. 30).

Mandrake é uma personagem atraente, com características misturadas, e não pode ser classificado como herói nem como anti-herói. A presença do herói só é aceita em uma sociedade em que a lei e a ordem estão bem estabelecidas. $\mathrm{O}$ detetive clássico é o modelo de herói moderno, infalível, representante da ordem. Com o romance negro, surge um novo tipo de herói, mais próximo da realidade, mas que ainda representa a ordem. Em Rubem Fonseca, o detetive foge dessa função, que já não cabe no mundo contemporâneo, em que não há mais espaço para papéis bem definidos.

$\mathrm{O}$ autor estabelece um diálogo crítico com o romance policial clássico e com o noir, jogando com a ideia do herói que age sem pensar, impelido pela paixão, característica muito encontrada nos detetives do romance negro: "Metido num mundo de artérias cortadas e órgãos perfurados, pensando em tornar-me um herói sinistro e vingativo, eu não podia ser boa companhia, nem para Ada nem para mim próprio" (FONSECA, 1983, p. 89). A certeza que caracteriza os romances policiais de enigma dá lugar à dúvida, às incertezas; o detetive contemporâneo é cético, desconfiado, imaginativo:

Talvez as coisas tivessem acontecido assim. Certeza eu não podia ter. Podia imaginar, concluir, deduzir não havia feito outra coisa naquela história toda. De qualquer forma eu estava muito próximo da verdade (FONSECA, 1983, p. 291).

No capítulo final de $A$ grande arte, não só a verdade é relativizada, como também a oposição detetive-criminoso, como percebemos nesse diálogo entre os detetives Raul e Mandrake:

"Ouça, Mandrake, essa história nunca foi contada direito. Você afirma que Lima Prado matou as massagistas, mas eu não tenho certeza disso."

"Está nos Cadernos."

"Você interpretou assim. Ninguém consegue ler aquela merda. Eu estive com eles nas mãos, já se esqueceu? Duvido que você tenha entendido direito aquela letrinha. Você também interpretou essa história de Rosa ter assassinado Cila. A única coisa que eu sei, com certeza, é que Lima Prado era um dos grandes do tráfico de entorpecentes, mas isso jamais poderá ser provado."

(...)

"E quem matou as massagistas?"

"Pode ter sido qualquer pessoa. Pode ter sido você, Mandrake."

"Acendi um Panatela, escuro, curto."

"Abre outra garrafa, eu disse, e explica melhor como fui eu."

"Uma delas foi ao teu escritório, a outra saiu com você, na véspera de aparecerem mortas."

(...)

"Só comprei a Randall depois que elas foram mortas. Eu não sabia usar uma faca antes. E ainda não sei."

"Desenhar um P qualquer um desenha. E estrangular, a gente nasce sabendo. Você inventou que decifrou os Cadernos e pode, assim, inventar a história que quiser." (FONSECA, 1983, p. 295-96).

No trecho citado fica claro que os métodos utilizados por Mandrake para solucionar os crimes não são confiáveis. Tudo foi deduzido, imaginado, interpretado pelo detetive, e a verdade dos fatos passa a ser inatingível. Percebemos um diálogo crítico em relação ao policial clássico, pois, além de a idoneidade do detetive ser questionada e o mistério não ser solucionado, ao ser colocada em questão a possibilidade de o próprio detetive ser o autor dos crimes, há a quebra do pacto do gênero policial de que o detetive jamais pode ser o culpado.

\section{Conclusão}

A personagem é um "ser de papel". Não é propriamente uma representação do ser, mas tem uma ligação com ele, ou seja, espelha, de alguma forma, um ser real. Percebemos que as personagens sofrem influências da época em que surgem, e esse efeito da época é marcante na configuração da personagem detetivesca.

No século XIX, época entusiasmada com a crença positivista de que o conhecimento científico é a única forma de conhecimento verdadeiro, vemos surgir a figura de um detetive que é o protótipo do herói moderno, uma "máquina de pensar" que vem resgatar a ordem através do raciocínio lógico. Esse tipo de personagem só é verossímil em uma sociedade como aquela, em que as realidades são muito claras, e as fronteiras entre ordem e desordem, bem e mal, são bem definidas.

Já no século XX, com todo o caos provocado pela quebra da bolsa de Nova Iorque, que ocasionou a Grande Depressão, um detetive como Dupin, que soluciona o enigma sem se envolver fisicamente, utilizando apenas a mente, seria considerado inverossímil. Surge então a figura de um detetive pessimista, "durão" e amoral, que se envolve na perseguição dos suspeitos e que, em lugar 
do raciocínio lógico, utiliza a intuição e a experiência para solucionar os crimes.

A ficção policial que floresce no Brasil por volta de 1980 inspira-se nos detetives americanos, mais condizentes com a nossa realidade. Esse detetive contemporâneo é reflexo de uma época que perdeu a inocência. Ele não é mais visto como um herói, pois este só é possível em um mundo no qual as dicotomias são bem marcadas e há clareza das dualidades. No contexto contemporâneo, não há mais a crença em verdades absolutas, e os conceitos passam a ser relativizados.

Assim, após observações e deduções criteriosas, concluímos, com a confiança típica de Dupin, que a personagem detetivesca - seja ela cerebral como Sherlock Holmes, intuitiva como Samuel Spade, ou imaginativa como Mandrake -, está sempre em consonância com o contexto social no qual se insere, e podemos dizer que se tornam mais complexas com o tempo. São personagens redondas, na concepção de Forster, são "dinâmicas, são multifacetadas, constituindo imagens totais e, ao mesmo tempo, muito particulares do ser humano" (BRAIT, 2004, p.41). E serão sempre fascinantes, pois representam um dos pontos mais antigos e inquietantes vivenciados por nós: a busca por respostas.

\section{Referências}

ALBUQUERQUE, Paulo de Medeiros e. O mundo emocionante do romance policial. Rio de Janeiro: F. Alves, 1979.

BENJAMIN, Walter. Charles Baudelaire: um lírico no auge do capitalismo. São Paulo: Brasiliense, 1989.

BOILEAU, Pierre; NARCEJAC, Thomas. O romance policial. São Paulo: Ática, 1991.

BRAIT, Beth. A personagem. São Paulo: Ática, 1985.
CANDIDO, Antonio. A personagem do romance. In: $A$ personagem de ficção. São Paulo: Perspectiva, 2009. p. 51-80.

CARNEIRO, Flávio. Das vanguardas ao pós-utópico: ficção brasileira no século XX. In: No país do presente: ficção brasileira do século XXI. Rio de Janeiro: Rocco, 2005. p. 13-34.

DOYLE, Conan. Sherlock Holmes. Vol. I: Romances. São Paulo: Martin Claret, 2014.

FIGUEIREDO, Vera Lucia Follain de. Os crimes do texto: Rubem Fonseca e a ficção contemporânea. Belo Horizonte: Ed. UFMG, 2003.

FIGUEIREDO, Vera Lucia Follain de. O assassino é o leitor. In: Matraga - Revista do Instituto de Letras da UERJ, v. II, n. 4-5, p. 20-26, jan.-ago. 1988.

FONSECA, Rubem. A grande arte. Rio de Janeiro: Francisco Alves, 1983.

FORSTER, Edward Morgan. Aspectos do romance. Rio de Janeiro: Globo, 2005.

FOUCAULT, Michel. Vigiar e punir. Petrópolis: Vozes, 1999.

JAMES, P.D. Segredos do romance policial. São Paulo: Três Estrelas, 2012.

MANDEL, Ernest. Delícias do crime: história social do romance policial. São Paulo: Busca Vida, 1988.

MEYER, Marlyse. Folhetim: uma história. São Paulo: Companhia das Letras, 1996.

PIGLIA, Ricardo. Sobre o gênero policial. In: O laboratório do escritor. São Paulo: Iluminuras, 1994.

POE, Edgar Allan. Os crimes da Rua Morgue e outras histórias. São Paulo: Saraiva, 1961.

Recebido: $15 / 11 / 16$

Aprovado: 30/03/17

Contato: mnebias@hotmail.com 